\title{
International practice of commercial registration
}

\author{
by Dr Timo Holzborn and Dr Sabine Leube LL M
}

This article presents an overview of the registration practices of a selection of national commercial registers, a subject matter of increasing importance for the international commercial practice.

\section{INTRODUCTION}

I nvestors and companies with international business ties are becoming more and more aware of the benefits of international harmonization as well as the remaining pitfalls of local registration practices. Recent court decisions in Europe have stressed the relevance of legal issues arising in the context of what is or is required to be disclosed in national commercial registers and what the legal consequences thereof are - a question of particular interest within the growing European Union and also for foreign entities with overseas activities.

A thorough understanding of the role of national registration systems becomes especially relevant in the light of two recent decisions of the European Court of Justice (ECJ) dealing with the effects of the freedom of establishment under EU law. In one of these cases, a local regulation under Dutch law providing for certain registration requirements with respect to branch offices of foreign (as opposed to Dutch) companies was deemed a violation of the freedom of establishment (ECJ, decision of September 9,2003, Rs. C-167/01 (“Inspire Art”)). Under this regulation, which the court repealed, a company was forced to register as a so-called "formal foreign company", to restrict its commercial legal activities accordingly and to comply with such provisions as minimum share capital and special directors' liability. Another well-noted decision of the ECJ (ECJ, decision of November 5, 2002, Rs. C208/00 ("Überseering") similarly concerned the issue of freedom of establishment and came to the conclusion that any regulation of the legal status of a company according to the rules of the applicable local law must be taken into account when moving the corporate seat to another EU jurisdiction. It will therefore always be relevant which regulations an EU Member State sets forth with respect to the issues of incorporation and status.

The ECJ decisions will be of interest to both EU and foreign investors planning to establish a branch office within the EU. Following the view of the ECJ, it might be advantageous for them to move their business to an EU Member State which offers a less restrictive corporate law regime (and also consider other relevant factors, such as the strict participation requirements under German labour law). Here, the article reviews the status of European harmonization efforts and points out remaining differences between several EU Member States.

Another aspect of the international practice of commercial registration is the imminent danger of shortfalls in payment due to the fact that especially small and mid-size companies are often unable to adequately estimate the solvency of their business partners. This situation has been declared the basis of an enormous increase in the number of insolvencies in Europe (for Germany, see Helmut Rödel, Handelsblatt, December 5, 2002, pp 1 et seq). Despite the continuing rise of the new media, the collection and assessment of company data of even large companies at the contractual pre-signing stage still entails a number of difficulties. Frequently, situations have arisen where early-stage information and assessment practices would have been able to implement precautionary measures.

In the Comroad $A G$ case for example (overview over claims of liability with respect to losses incurred by investors, Holzborn/Foelsch, NJW 2003, 932) a company indicated high turnovers by the use of fictitious foreign companies - one reason to give importance to the collection of data in the securities and stock exchange context. Because of this, the article widens its focus on the registration practices of certain EU Member States by including a description of the respective commercial registers and their effects relating to disclosure and third party reliance.

\section{HARMONIZATION AT EU LEVEL}

Very early on, the various legal traditions of commercial registration in Europe led to attempts at harmonization. The EU Council's First Company Law Directive, dated September 3, 1968, 68/151/EEC (see also Lindhorst, CR 1998, 590, 595 f) - the so-called "Disclosure Directive" was already a first step, later amended by the EU project "European Business Register". 


\section{(i) The Disclosure Directive}

This first attempt towards harmonization of disclosure criteria in the EU was limited in that it only required every Member State to provide for a commercial register in which to enter the relevant information. Only those corporations or partnerships that satisfied certain liability criteria were affected by the mandatory registration of article 1 of the Disclosure Directive (with respect to certain types of corporations, only the disclosure of annual accounts is mandatory - see art 2 para 1 et seq of the Directive). The applicability of the Directive broadened in 1989 (Eleventh Company Law Directive, 89/666/EEC) with the inclusion of branch offices of foreign limited liability companies and one-person companies (ie companies with only one owner). In this case, the name of the sole liable shareholder must be disclosed. Articles 2-6 of this 1989 Directive required disclosure of a company's articles of association, management, and amount of the liable share capital as well as respective changes and annual accounts.

Beyond that a system of dual disclosure was established: the entry into the register supplemented by an announcement in a periodical publication. Different legal traditions remained, however, with respect to whether or not a substantive review of the registered content was conducted by the respective authorities. Similarly, the Community did not attempt to regulate the registrars themselves (registrars can be either courts or special agencies, as well as chambers of commerce or other like authorities ).

Article 3(4)(2) of the Directive provided for a so-called negative disclosure effect for information made public and entered into the register (see III(i) below for a further description of the various effects of disclosure). Accordingly, a third party may only become subject to an item required to be disclosed where a corresponding announcement has been made or the third party otherwise knows of such information. This abstract approach to protecting trade is amended by a limited positive disclosure. Where the disclosed information deviates from the actual contents of the register or the filing, good faith protection is offered to third parties. Such protection, however, does not extend to the level of a general positive disclosure effect.

\section{(ii) European Business Register}

Since 1992, the European Business Register project has pursued the simplification of acquiring information on company data - so far 12 Member States are participating in this project, supported by the European Commission. After the first two phases of the project, the EBR EEIG became the official operator of the European Business Register, which it is continuing to develop, with the Commission keeping contact with Member States. The project aims to provide a fast and affordable way to acquire information from the respective registers. The participating countries are currently Austria, Belgium, Denmark, Finland, France, Greece, Italy, Latvia, Norway, Sweden and Spain. Germany has been considering whether to use data provided by its commercial chambers (see Lindhorst, CR 1998, 590, 597) and has meanwhile been building relations to the private provider of company data ecofine.

Private providers located in the participating countries access the register's information and forward what is needed. As a result, an interface has been built up which operates between the non-affiliated registers without centralization, as information is still gained from the local registers. This activity is especially welcomed by small and mid-size companies aiming to lower their transaction costs relating to the acquisition of company data. Reducing the risk for the creditor also facilitates international trade (see Hubalek/Reichelt, Europäisches Handelsregister II (European Commercial Register II), Vienna 2001, pp 51-2). However, problems arise because information continues to conform only with the prevailing standard in the individual EU Member States based on the provisions of the Directive.

\section{(iii) $E \boldsymbol{U}$ initiatives}

In 1999, the SLIM-Initiative - Simpler Legislation for the Internal Market - conducted a review of EU-wide disclosure of company data, and indicated the need for further action (see Report of the Commission to the European Parliament and the Council, Results of the Fourth Phase of the SLIM-initiative, KOM 56 (2000), p 3). One proposal was the electronic registration of company documents and the availability of such information in other official EU languages (see Van Hulle/Reichelt, Europäisches Handelsregister II (European Commercial Register II), Vienna 2001, p 9). The idea is, following a transition period, to replace hard copy filings by an electronic registration (Noack, BB 2001, 1261, 1267). Furthermore, in view of article 9 paragraph 3 of the Directive, it was also proposed to impose mandatory registration on authorized representatives in addition to the already existing obligations of management.

The Commission, however, sees the need for further analysis and review prior to yet another amendment of the Directive (see Report of the Commission to the European Parliament and the Council, Results of the Fourth Phase of the SLIM-initiative, KOM 56 (2000), p 4). The Member States confirmed the need for reform and also emphasized the importance of general accessibility to the data that was required to be disclosed (see Van Hulle/Reichelt, Europäisches Handelsregister II (European Commercial Register II), Vienna 2001, p 10). 


\section{EU MEMBER STATES}

The Directive's limited application with respect to certain corporations points to holes in the harmonization effort. Selected EU Member States are examined below in order to highlight the different situations relating to registration, supplemented by an analysis of Switzerland and North America.

\section{(i) Germany and the concepts of disclosure}

The commercial registers in Germany are operated by the local courts (Amtsgerichte). The registered data is publicly accessible, and no special interest in its contents must be claimed in order to view an entry (s 9 para 1 of the German Commercial Code (HGB) states that everyone is entitled to view the registered data and any documents filed with the register). An excerpt of the registered data can be requested (s 9 para $2 \mathrm{HGB}$ ). According to section $10 \mathrm{HGB}$, the courts are obliged to make new entries public, which is done by respective announcements in the federal paper (Bundesanzeiger) and at least one additional periodical.

Registration is mandatory for a number of companies as well as with respect to certain "commercial data", such as the name and seat of an individual commercial business, the existence (and likewise the termination) of a general power of attorney, or the creation and termination of closed corporations. Both stock corporations (Aktiengesellschaften-AG) and limited liability companies (Gesellschaften mit begrenzter Haftung-GmbH) - two important corporate forms when it comes to international trade - require registration. In both cases, registration has a constitutive effect - without registration they do not “exist". Section 41(1)(1) German Stock Corporation Law $(A k t G)$ provides that before entry into the commercial register the AG does not exist as such (see also s 11 para 1 German Limited Liability Companies Law $(G m b H G)$ with a corresponding rule). In other cases - such as registration of the existence of a general power of attorney registration merely displays a declaratory effect.

In Germany, the first truly electronic commercial registers in operation were created on a state level in the local courts of Essen, Cologne and Düsseldorf in the fall of 2000. In view of the gradual conversion of 30 courts in the state of North Rhine-Westphalia alone, and the input of old data into the system, this system could still take a few years to complete. The law governing electronic registers and legal costs for telecommunications (ERJuKoG, dated December 10, 2001, BGBl. I S. 3422; also see Seibert, BB 2001, 2494; Noack, BB, 2001, 1261) provides for a new system of allocating company data in the register.

The provisions on registration in German law give a good example of the different effects of disclosure. Besides the already mentioned distinction between constitutive and declaratory registration, an entry into the register may affect third parties in their reliance on what has - or what has not - been registered. One major function of the register is that of good faith protection. Under section 15 HGB, three types of disclosure effects can be distinguished: the so-called "negative", "positive" and "general" publicity or disclosure (compare Baumbach/Hopt, HGB, 30th Ed., Munich, 2001, § 15 at 1). According to the principle of negative disclosure, third parties can rely on the "silence" of the register, ie must only consider data which has been registered and announced unless the third party otherwise has gained positive knowledge of such data. The concept of "general" disclosure, as regulated under section 15(2) HGB, provides that third parties cannot claim ignorance of a registered fact. It is limited in so far as the third party enjoys a period of 15 days after announcement during which a registered fact may not be held against it, provided that it is able to prove its ignorance.

Finally, the effect of positive disclosure allows the bona fide third party to rely on an incorrect contents of registered data, but only in relation to the registrant itself. Thus, German law does not establish a broad positive publicity, the effect of which would be create trust in the correctness of the registered content.

\section{(ii) Great Britain}

The British Companies Houses are public registers operated by state agencies on a regional level. Although separate registers exist for England \& Wales, Scotland, Northern Ireland and the Channel Islands, it is possible in part to centrally access these registers online (see http://www.companieshouse.gov.uk). There, an account may be opened with "Companies House Direct" (for which a one-time fee of $£ 50.00$ and a monthy subscription fee of $£ 7.50$ applies) to access company information. For certain businesses, however, only a local request can be made. Registration is mandatory for stock corporations and for limited liability partnerships. Stock corporations are grouped according to their liable share capital into limited by share, limited by guarantee and unlimited by shares. In addition, private and public companies are treated differently, with a higher level of disclosure required for the latter.

Public limited companies ("PLCs") are required by section 118 (1) Companies Act 1985 to have a minimum share capital of $£ 50,000$. Partnerships without limited liability of the owner do not have to file with the register; the owners of this type of partnership are generally personally laible for the obligations of the partnership. Limited liability partnerships are treated like stock corporations and are therefore required to register: if a company's existence is terminated, its members are under an obligation to contribute to the outstanding liabilities, as provided for in the Limited Liability Partnerships Act 2000. The extent of registration is limited to the name, the legal form, the liable share capital, the articles of association and their respective amendments, as well as the 
annual returns (see further the list offered by Farrer, Company Law, 4th Ed., London 1998, pp 87-8).

A substantive review by the office of the registry is limited to the lawfulness of the company's activities and the company name. Beyond that, the registrar only looks at the completeness of a filing. The register's publicity does not offer third parties a good faith protection that goes beyond that of the Directive (see also Official Custodian for Charities v Parway Estates Developments Ltd [1985] Ch 151, CA). In addition to negative disclosure, where a protection period of 15 days applies, a limited positive disclosure effect also exists. The entry into the register leads to the issuance of the constitutive certificate of incorporation by the registrar, but since this may also be based on a conditional shareholder resolution, one cannot infer the lawfulness of incorporation from the registration itself.

The Registrar's duties remain substantial after incorporation. A PLC, for example, may not do business or exercise any borrowing powers until the issuance of a certificate of the Registrar stating satisfaction that the PLC complies with minimum capital requirements (s 117 (1) Companies Act 1985).

\section{(iii) France}

The French registre de commerce et sociétés is organized locally with the commercial courts. These regional entities are supplemented by a central register in Paris at the Institut National de la Propriété Industrielle (INPI), where duplicates of all locally registered information can be viewed on file (see http://www.inpi.fr). Independent businessmen are required to register, filing their name, date of birth, address and their personal and domestic status as well as any previous convictions. Furthermore, every company must at least register the company name, seat, legal form, object of the company, liable share capital and the company's representative. Companies in this sense include the société en nom collectif, the société en commandite, the société à responsabilité limitée, the société anonyme, and the société en commandite par actions. The société en participation is not able to register. Foreign companies opening a branch office or agency in France are also required to register.

The review of the submitted documents is limited to completeness and compliance with the law. Further to the negative disclosure effect, there is an assumption of a registered person's qualification as "business person" and a liability for registered obligations in the event of a transfer of company assets (art 64 of the decree no. 84-406). The entry has a constitutive effect for stock corporations regarding their legal existence; otherwise registration only has a declaratory function (Chaussande-Klein, Gesellschaftsrecht in Frankreich (Corporate Law in France), p 45).

\section{(iv) The Netherlands}

The commercial register in the Netherlands (operated on a legal basis since October 1, 1997, of the Handelsregisterwet (1996) and the Handelsregisterbesluit (1996)) is assigned on a local level to the 21 chambers of commerce (see http://www.kvk.nl). Those legal entities capable of being registered are private companies, commercial companies (Vennootschap onder firma, commanditaire vennootschap, besloten vennootschap, naamloze vennootschap), associations, mutual benefit associations and foundations (see Gotzen, Niederländisches Handels- und Wirtschaftsrecht (Dutch Commercial and Economic Law), Heidelberg 2000, p 22). The minimum registration requirements include, according to article 9 of the Handelsregisterbesluit, the company name, seat and address, legal form, object of the company, liable share capital, modalities of representation, and their respective changes (see Haarhuis, Gesellschaftsrecht in den Niederlanden (Corporate Law in the Netherlands), 1995, pp 21 et seq).

A substantive review of the facts entered does not occur, and the entry serves only for declaratory purposes. A bona fide third party can rely on such facts which were not registered despite an obligation to do so (negative publicity). Likewise, lacking notice, such third party may rely on the original content of the register for up to 15 days after a change of the entry. Article 23 Handelsregisterwet requires third parties to rectify incorrect information on the register.

\section{(v) Belgium}

The Registre de Commerce/Handelsregister is organized as a public corporate register at the commercial courts (Lois coordonnées relatives au rgistre du commerce/Handelsregisterwet of September 20, 1964, Arrête Royal/Konikijk Besluit of August 18, 1964, August 31, 1964, May 31, 1991). Moreover, copies are made available for inspection at the Registre Centrale du Commerce/Centraal Handelregister in Brussels (see http://www.eurodb.be). Independent businessmen and companies can register société en nom collectif/vennootschap onder firma, societé en commandite/ commanditaire vennootschap, societé à responsibilité limitée/ besloten vennootschap, societé anonyme/naamloze vennootsch. A separate register is kept for mutual benefit associations, civil law companies, associations and craftsmen.

The minimum recording requirement comprises the name, seat/address, legal form, object of the business, liable share capital, and representation modalities as well as any respective changes. The right of the registrar to review the completeness and lawfulness of the submitted documents hardly meets the requirements of a formal examination (see Knechtel/Reichelt/Zib, Europäische Handelsregister 2000, p 94). Even in the case of stock corporations, registration only has a declaratory effect, since the legal status already results from the act of incorporation. In Belgium, negative publicity exists with 
respect to facts that are not recorded. With the exception of the sale of a company, no protection is given in the sense of reliance on the accuracy of registered information (see Knechtel/Reichelt/Zib, Europäische Handelsregister (European Commercial Law), Vienna 2000, p 94).

\section{(vi) Italy}

The Registro delle Imprese as a corporate register resulted from the unification of the commercial register and the company register in 1996 (Decree of December 7, 1995, D.P.R. $581-112 / 98$ and the Law on the Reorganization of the Chambers of Commerce (L 580/93)). The register consists of the sezione ordinaria and the sezione speciali, with the latter containing the data of farmers, small business entities, civil law companies and craftsmen. Under the supervision of a registrar judge, the register is organized in a decentralized manner at the chambers of commerce in the provinces (see http:// www.infocamere.it). Within 30 days of their creation, stock corporations (società per azioni, società a responsabilità limitata, società in accommandita per azioni), trade companies (società in nome collettivo, società in accommandita semplice), mutual benefit associations, civil law companies, craftsmen, farmers and individual business entities must be registered. For civil law companies, registration is not mandatory but merely a formal act.

The minimum content that must be entered into the register includes the essential characteristics of the enterprise - name, seat, legal form, purpose, names, date of birth and address of the shareholders (requirements for registration are laid out in the Codice Civile, Art 2196 et seq). Details of capitalization and modalities of representation are required - members of management and other signatories for the company, the type and scope of representation and further details on the individual representative. The date of the creation and the last amendments of the articles of association are also required (for details, Kindler, Italienisches Handels- und Wirtschaftsrecht (Italian Commercial and Economic Law) (2002), pp 72 et seq).

Registrations are subjected to a purely formal review and they generally - with the exception of stock corporations only have declaratory effects. One exception to this rule is general powers of attorney, and in this case, registration has a constitutive effect (see Hofmann, Gesellschaftsrecht in Italien (Corporate Law in Italy), pp 20-2). Disclosed facts only create a good faith protection in so far as a third party in good faith may rely on incorrectly registered information. Apart from this, a negative disclosure effect exists for facts that are not entered.

The Italian approach to registration exhibits an interesting characteristic vis-à-vis online accessibility. Anyone who pays a fee can view and print information via the internet, but the printout does not have the validity of an official certification (see www.itkam.de, www.infocamere.it, www.ipsoa.it/ infocamere/ presentazione .asp). Since 2001, all registrations may exclusively be submitted electronically (see Law no. $349 / 2000$, art 31 para II) in order to save cost and time.

\section{(vii) Spain}

The operation of the Registro Mercantil -Articles 16-24 of the Código de Comercio (Ccom ) and the Reglamento del Registro Mercantil Real Decreto 1748/1996 of July, 1996 (RRM) - lies in the hands of local registers, while the Registro Mercantil Central in Madrid exercises a purely informational function (see http:// www.rmc.es).

Registration is mandatory for corporations - sociedad anónima, sociedad de responsabilidad limitada, sociedad comanditaria por acciones, sociedad colectiva, sociedad comanditaria, cooperativa, sociedad de garantia recíproca, sociedad laboral, naviero empresario individual - and other legal subjects such as credit institutes and associations, insurance companies and pension funds (art 81, no.1 RRM). For individual businessmen, however, the entry is voluntary, but when made results in certain protections through disclosure. Also, civil law companies may be registered and thereby assume a form corresponding to that of other corporations (Rueda Martinez/Hohloch, EU-Handbuch Gesellschaftsrecht (EU Handbook on Corporate Law), Spain, at p10). As a minimum requirement, registrants are generally required to file the articles of incorporation, details of management, corporate changes and branch offices as well as their corresponding changes.

The voluntary entry for individual businessmen according to Article 19 paragraph 2, CCom requires, apart from filing the name, object of business and the initial date of business, disclosure of the domestic status as this can justify or exclude the joint liability of a spouse. The lawfulness of the submitted documents, and their legal efficacy as well as the authorization of the applicant are examined prior to entry (art 6 RRM). A negative disclosure effect is supplemented by the protection of bona fide third parties. Information required to be registered may not be held against a third party within 15 days after the publication, if the third party proves that knowledge thereof could not have been obtained (art 21, no. 2 Ccom).

If a registration is incorrectly announced the third party has the right to rely either on the correct contents of the entry or the contents of the specific announcement (art 21, no 3 CCom; Carsten-Lichterfelde/Löber/Peuster, Aktuelles Spanisches Wirtschaftsrecht (Present Spanish Economic Law), 1991, p 25). This, however, does not give any legal effect whatsoever to an announcement which is not based on a registered fact (art 21, no $1 \mathrm{CCom}$; the reversion of the burden of proof under para 4 further enhances this protection). In Spain, too, an entry is constitutive only with respect to a company's legal status (see Cremades, Gesellschaftsrecht in Spanien (Corporate Law in Spain), 3rd Ed, 2001, pp 57-8). 


\section{(viii) Portugal}

Entries into the Registo del Commercial - Decree Lei no. 403/1986 of December 13, 1986 and Portaria no. 883/1989 of November 13, 1989 - are made by the responsible Conservatòria do Registo Comercial. In the case of corporations, registration can in general only be undertaken after receipt of a certification of admissibility and preliminary proof of the act of incorporation at the national register - Praca Silvestre Pinheiro Ferreira, 1 C, Lisbon (address: Registo Nacional des Pessoas Colectivas, Apdo, 4064, 1502 Lisbon Codex). Registration is mandatory only for stock corporations acting as trade companies and closed corporations with limited liability such as the sociedade em commandita - the mutual benefit association is generally unable to register.

In practice, the Sociedade por Quotas is the preferred form of incorporation because, compared with the Sociedade Anómina, this form offers a much simpler administrative and supervisory structure. In the case of the Sociedade Anómina, payment of up to $70 \%$ of stock may be delayed for up to five years. Furthermore, incorporation can take place through public or private placements. For stock corporations, registration is made by submission of a notarized certification of the articles of incorporation. According to Article 5 C.S.C. (Còdigo das Sociedades Comerciais), an entry has a constitutive effect with respect to the creation of a stock corporation (Cremades/Peinando). Information required to be registered may only be held against a third party if there was a corresponding announcement or such third party otherwise became aware of the registered fact. This abstract regulation is supplemented by a limited positive disclosure effect creating protection if the disclosed information deviates from the actual registered contents. A general positive disclosure effect does not exist.

\section{(ix) Austria}

Since 1999, a Firmenbuch has replaced the commercial and mutual benefit associations' register. It operates as an electronic, publicly-accessible register that can be inspected without statement of a legal interest upon payment of a small fee. It is kept in the state courts, and administered by a magistrate or clerk who undertakes a purely formal review during an entry. Besides stock corporations, closed corporations, mutual benefit associations, savings banks and private foundations, those capable of registration include individual businessmen. Company details that must be filed include name, legal form, seat, shareholders and business objectives and, in the case of individual businessmen, name and date of birth.

The liable share capital and essential changes thereto especially including payments made on the share capital and corporate reorganization - as well as the type and extent of any right of representation, must also be included. The solely electronically-made entries (Lindhorst,
CR 1998 590, 597) generally only display a declaratory effect, with the exception of stock corporations and mutual benefit associations in which cases an entry into the register is constitutive. The negative disclosure effect is supplemented by a limited positive disclosure effect protecting good faith reliance on incorrect announcements (Knechtel/Reichelt/Zib, Europäische Handelsregister (European Business Register), Vienna 2000, pp 60 et seq).

\section{(x) Czech Republic}

In the Czech Republic, the commercial register is operated by registry courts. The obligation to register and general provisions for all commercial companies are contained in the Commercial Code no. 513/1991. Registration is mandatory for corporations which, among other items, enter their name, seat, identification number, legal form, business objective, management, and share capital. It is possible to access the register directly via the internet. The website of the Ministry of Justice (http://www.justice.cz) offers information on the company's corporate history beginning with its first registration. Although this information is not of a legally binding character, it can be accessed immediately. Registration does not only have a constitutive effect on the incorporation of a company, but also on other measures such as the increase or reduction in the share capital, share pledges (in the case of limited liability companies), partition or change of the legal form and the types of stock.

Apart from the entry, essential documents of the company are also kept in a collection of deeds (s 27a et seq Czech Commercial Code no. 513/1991; these include, the articles of incorporation, articles of association and any amendments thereto). The contents of such documents, which are required by law to be disclosed, can only be held against a third party once they have been published (s 27 para 1 Czech Commercial Code no. 513/1991; further Štenglová/Plíva/Tomsa, Annotated Commercial Code, 2001, p 83). An exception is made only if the third party did not act in good faith.

\section{(xi) Slovak Republic}

Under Commercial Code no. 513/1991, all commercial companies must register with the commercial registers operated by the register courts. Stock corporations must file their liable share capital, name, seat and purpose of the company. With respect to limited liability companies, a minimum share capital of SKK 200.000 and a share of at least SKK 30.000 per shareholder are required. For a stock corporation, the share capital must be a minimum of SKK 1 million.

Among other data, the companies must file proof of the number and nominal value of each class of shares and the paid in share capital. If the liability of a shareholder of a closed corporation is limited, this likewise must be registered. In order to be recognized as a legal entity, the 
entry then has a constitutive effect. With respect to stock corporations, a certification of the articles of association elicits this same legal effect (see http://www.sario.sk). The review of the submitted documents is limited to a check for completeness (Petr Bohata, Gesellschaftsrecht in der Tschechischen Republik und der Slowakei (Corporate Law in the Czech Republic and the Slovak Republic), 1998 pp 10001). All in all, register practice in the Slovak Republic has become very similar to that of the Czech Republic (further information can be viewed at http://www.czechinvest.org).

\section{(xii) Poland}

With the introduction of the law on state court registers dated August 20, 1997 (Law 1997, no. 121, Poz. 769), the tasks and the duties of the commercial registers in Poland were redefined. It replaced the previously prevailing system by a public electronically-organized register. This register comprises sub-registers in the form of the corporate register, the register of the mutual benefit associations and other social institutions and labour foundations as well as the register of insolvent debtors. This register of insolvent debtors enters a new phase of registry practice and improves the prospects of succeeding with legal actions and their enforcement. The entry has a constitutive effect not only on the incorporation, but also with respect to changes to the registrant's articles of incorporation.

Requirements for registration are regulated by the decree on register practice of December 21, 2000. Part of the mandatory registration is the name, seat, and object of the company as well as information on the shareholders, amount of share capital and modalities of representation. Third parties can no longer claim ignorance of a specific fact once such information has been entered into the register. As long as a third party is in good faith, it is assumed that the registered data corresponds to the facts.

\section{(xiii) Hungary}

In Hungary, the companies register is organized in the form of a public company register and kept with the competent regional courts in their capacity as company courts. The provisions are contained in the 1997 law no. 145 on the company register. Moreover, a central corporate information service was instituted at the Ministry of Justice, which offers data of all company registers. Registration is mandatory for, among others, stock corporations, limited liability companies, partnerships, closed corporations, mutual benefit associations and branch offices of foreign corporations. Other business operators, so-called individual business persons, may register voluntarily. The extent of the obligation to register depends on the legal form of the company. Company name, seat, shareholders, share capital, auditors etc, must be registered, as well as all banks accounts and any liquidation, insolvency or foreclosure proceedings. The submitted documents, such as articles of association, resolutions, annual accounts are kept in a separate file.

All annual accounts must be filed with the company court and the official service of company data. The company court only keeps these on file, while the data service records them in an electronic format. All relevant changes must be reported to the company court within 30 days. The entry into the register has a constitutive effect and is recorded retroactively to the day the respective resolution was passed. Both a formal and a substantive review are conducted upon registration. The register carries with it a positive and a negative disclosure effect.

\section{SWITZERLAND}

Switzerland has generally accessible commercial registers, which are kept in the individual cantons. This is provided by section $930 \mathrm{OR}$ and section 9 Handelsregisterverordnung. Moreover, there is a central office for commercial registration. The advantages of an electronic register have been tested since December 12, 1997 by a comparison of electronic data between the cantonal and central commercial registers. The result of this comparison is used for the creation of the Zentraler Fimenindex available online (access to the regional commercial registers is via http://www.zefix.ch). Following an entry, the registrar undertakes a comprehensive review of the substantive and formal preconditions for the entry. The substantive review, however, is limited to obvious cases of unlawfulness (see, eg, decisions BGE 86 I 107, 114 II 70, 121 III 369; with respect to the extension of the scope of review, see de Beer, ZSR 1995 I, 81). Furthermore, those violations are relevant to the registrar that are of a global concern, and not only regarding the actual parties directly affected. According to section 934 paragraph 1 OR, registration is only mandatory if a commercial enterprise is concerned. If a company's purpose is acquisition thereof Article 2 only offers the possibility to file for an entry (see also s 52 para 3 Handelsregisterverordnung).

The entry has a constitutive effect with respect to stock corporations, certain stock limited partnerships, limited liability companies and mutual benefit associations as well as the non-commercial collective and limited partnerships. A merely declaratory effect exists only with respect to special commercial companies. Even if a third party is not aware of it, according to section 933 paragraph 1 OR, disclosed information may be held against it. On the other hand, facts not entered cannot be held against a third party. In this sense, there is a negative disclosure effect (but this effect is limited only with respect to a positive knowledge of the third party, see Meier-Hayoz/Forstmoser, Schweizer Gesellschaftsrecht (Swiss Corporate Law), 8th Ed., Bern 1998, s 6, at 72).

A good faith protection towards announced, yet, incorrect information is disputed as an explicit regulation does not exist. The majority of scholars believes that such 
protection exists when the third party enjoys a particular interest of protection in the individual case (eg in the context of an entry having a constitutive effect, see $B G E 78$ III 33, Gauch, SAG 1983, 137, 139).

\section{NORTH AMERICA}

\section{(i) United States of America}

An understanding of the situation in the United States is important in the context of international commercial register practices, in particular as there is no US concept corresponding to the European legal tradition regarding registration. Although international trade seems nowadays mostly concerned with the several filing requirements under the regime of the securities markets, it is essential to look at the general provision of the state corporate laws as well. In the US, "registration" falls into the responsibilities of the states. Although individual provisions may vary, state law in general sets forth that the certificate or articles of incorporation be filed with the Department of State. Corporate existence then begins with such filing. Later, a certificate of good standing can be issued as proof of the creation of a corporation. Unlike the approach in many European countries, changes to the shareholder structure are, in general, not filed for registration. There is no disclosure effect connected to either the registration or any announcement thereof.

\section{(ii) Canada}

Contents and the legal consequence of the entry into the commercial register are, depending on the type of incorporation and entry, partly determined by the individual provinces or by the state. The corporate register kept in each province shows whether a company was incorporated according to the Canada Business Corporation Act or the corporate and/or companies laws of the provinces (see http://www.laws.justice. gc.ca/en/C44/). A company must furthermore register in the province from where it operates. Registration is mandatory for the general partnership which can be created form-free, generally only in certain provinces (Saskatchewan, Ontario, Prince Edward Islands and Manitoba) whenever certain business objectives are pursued. The limited partnership, however, is always required to register. Without an entry into the register, such partnership is treated like a general partnership, with the consequence that its limitation of liability is no longer effective.

Stock corporations like the private or non-offering company, or the public company, use the designations "Ltd", "Incorporated" or "Corporation" and therefore cannot be further differentiated. The number of shareholders of a private company must not exceed 50 and their shares may not be freely transferred or offered publicly. The public company is subject to extensive disclosure obligations that include, in particular, financial reports and substantial structural changes. On the federal level, financial reports must be filed annually with the federal authorities and must be made accessible for the public if the world-wide assets exceed CAN 5 million or the returns exceed CAD 10 million. In Ontario, such disclosure requirements do not apply to a private company.

The articles of incorporation must be filed with the register. They contain the company name, share capital, any restrictions on the transferability of shares, the number of directors and restrictions on the operation of the business. The purely formal review is limited to completeness of the prescribed documents as well as the necessary fee payment. In the province of British Columbia, however, the modalities of incorporation correspond to English law. Here, a memorandum is required which contains the name of the company, restrictions on the company's business and powers-ofattorney, share capital and the names of the incorporators (see http://www.fin.gov.bc.ca/registries/corppg/default.htm).

\section{OUTLOOK}

The differences in registration practices - starting within the area of individual businessmen and closed corporations and extending to stock corporations - render both the collection of the relevant information as well as the analysis of the attained data difficult. If systems embrace electronic processing further, this will allow for more efficient and cost effective research in the foreseeable future.

The simplification of access to information, however, will not in itself solve the difficulties referred to above. Legislators will be required to improve commercial conditions through further reforms. The Single European Market has a pioneering role to play in this context, because only a further inclusion of small and mid-size companies into the reform efforts is able to guarantee a stimulation of international trade and at least substantially aggravate cases of fraud. The reactions to the report of the SLIM working group will hopefully lead to positive developments, in particular on the part of EU Member States. In addition, the case law of the ECJ with respect to basic freedoms will continue to have a substantial influence on the further formation of registration practices.

Dr Timo Holzborn is a German attorney-at-law (Rechtsanwalt), and Dr Sabine Leube $L L M$ is admitted to practise in Germany, a non-practising solicitor of England \& Wales and attorney-at-law (NY). Both work at the law firm of Nörr Stiefenhofer Lutz, Munich, Germany. The authors thank Mr Alexander Israel for his support. 